\title{
THE PHENOMENON OF LANGUAGE GAMES AS COLLEGE STUDENTS RESPONSES TO THE REVISED CRIMINAL CODE DRAFT 2019: A SOCIOLINGUISTICS STUDY
}

\author{
Nurul Nisfu Syahriy; Ridwan Hanafiah ${ }^{2}$; Rudy Sofyan ${ }^{3}$ \\ Universitas Sumatera Utara ${ }^{1,2,3}$ \\ Corresponding email: nurulnisfusyahriy@students.usu.ac.id
}

\begin{abstract}
A language game is a form of utterance that obtains various deviations, which is intended for various purposes and contains of more than one meaning that depends on how it used and to whom it is intended. In connection with this topic, this paper was made to analyze the phenomenon of language game originating from among students in some demonstrations aimed at the government especially the House of Parliament (DPR) regarding the revised criminal code draft (RUU KUHP) 2019 that was launched to be ratified. For this reason, the data used are portraits of posters and banners sourced from various cities in Indonesia with various forms of utterance. Accordingly, this study will analyze the data based on sociolinguistic studies to understand language problems related to the elements and functions of language. Data were analyzed using a descriptive qualitative method. Eventually, there were various forms of language games that were found such as, sound substitution, sound addition, abbreviations, metaphor, polysemic, idiom, entailment and rhyme. The language game mentioned was created with various objectives such as criticizing related policies, making fun of the related performance and just creating humor.
\end{abstract}

Keywords: language game, draft revised criminal code 2019, sociolinguistics

\section{INTRODUCTION}

Language along with the development of technology has developed rapidly and undergone many changes in its use. In line with one of the characteristics of dynamic language, many new terms emerge and circulate in society. These terms sometimes come from adaptations of foreign languages or even regional languages. The phenomenon of the emergence of 
new terms, one of which is caused by language that balances knowledge by being a means of conveying and delivering knowledge from one side to another. This is in line with the thought of Foucault (2018) a French poststructuralist philosopher who claims that language is the absolute intermediary for every knowledge. Therefore, the existence of knowledge such as the emergence of things, conditions or thoughts that never existed before will be the driving force for the emergence of new terms in a language.

Based on the explanation above, it is natural that new terms are coined to name something new. However, oddities will arise when the existing terms are interpreted and used differently. This phenomenon is known as a language game introduced by Wittgenstein. The language game according to Wittgenstein is that language always depends on how words are used (Wittgenstein, L., \& Brown, 2017). Thus, this allows the occurrence of plurality or the existence of more than one truth, so language will be difficult to ascertain (Wibowo, 2006, p. 61). For example, the word "Tikus Kantor" (office rat) has several meanings such as (1) people who spend most of their time in the office, (2) people who commit dirty acts in the government or in literal (3) a rodent mammals with various medium-sized and long tails that live in the office. Based on the three meanings before, every meaning is correct according to the situation attached to it. If it is related to the act of corruption, then correct meaning will be number (2).

One of the phenomena of language game is found on posters and banners owned by college students during demonstrations. The posters and banners contained protests and criticism from students in rejecting the RUU KUHP 2019 (The Revised Criminal Code Draft 2019). During the demonstration, it is common that the writing appearing on the posters and banners contains words of sarcasm, but the matter of concern in this study was a form of language game in it. It is because the words could not be interpreted literally, but depending on the situation, conditions and what happened behind the writing.

Fuady (2005, p. 114) states that language is something uncertain, which requires interpretations, so that language is also one of the causes of the emergence of elements of subjectivity and non-neutrality in the making and application of the law. It can be said that the language contained in the RUU KUHP 2019 is also included in the uncertainty expressed by Wittgenstein, where the law may cause non-neutrality and imbalance that might benefit one side only as feared by the demonstrators.

Research on language games in society has been done by many previous researchers. Saputri (2015) in her article examined the language game on a motorized license plate and found that the creation of the license plate aimed to convey what was the thought and feeling in communicating. 
The weakness found in this study is that there is no explanation of the social factors that are linked to the data.

Fatonah (2017) also explained about language games. In her thesis, she discusses language games in phonology, morphology, and semantics in the humorous discourse on "Meme Comic Indonesia" on Instagram. In the research results, it is known that there is a use of language games in the field of phonology in the form of substitution; in the field of morphology in the form of abbreviated languages; and semantic fields in the form of homonyms. The strength of this research is the finding that language games can be implicated in Indonesian language learning in anecdotal text material, so that they can become a reference for teachers in providing variations of learning.

Kinantia \& Nurdahliah (2018) in their journal discussed language games as an experiment in improving student achievement in morphology courses. This research is a type of quantitative research that discusses the influence of the use of language games. In the analysis, it was found that the provision of text in the form of language games proved to be able to provide an increase in exam scores in the morphology course of students. There is a weakness in this research in the form of an absence of explanation regarding the form and type of language games used in improving student achievement in the course. Then, Hartini (2019) explains the use of the rules of legal terms in a different context, but has a family resemblance. It was found that the meaning of the language game in UUD 1945 has rules that syntactically coincide with the logic of language and pragmatically by the facts that occur in the field.

Based on some of the previous research above, this research will be made to continue the previous research that has been done using different data to find out how language games use. Simply put, the purpose of this writing is an analysis of language games written on posters and banners of college students who reject the existence of the RUU KUHP 2019. This is done to find out the meaning of the text listed on posters and banners and the possibility of language distortion which led to the creation of language games.

The study was conducted based on an analysis of sociolinguistic studies that examined the relationship between language and social society. This is done to find out why people communicate differently, as well as to study the elements and functions of language in conveying social messages. In other words, this analysis is carried out with the primarily aim of knowing how the public expressed their criticism of the government and how language is used briefly but contains profound meanings about what is in their minds towards related policies. Furthermore, the analysis will be 
explained based on a qualitative-descriptive method supported by library research.

The structure of this writing is preceded by an introduction that contains the background of this research. The writing is followed by a brief description of the theories and concepts that underlie research analysis, followed by a description of the research methods used. The findings and discussion will be the next part, followed by the conclusions of this paper.

\section{METHODS}

Stages in language-related research start from the search or discovery of problems, which are then continued by several subsequent stages. Sudaryanto (2015a, p. 6) explained the stages as an effort to solve the problem in sequence, namely, (1) The stage of providing data, where several portrait posters and banners were provided until the data was reliable as an analysis material; (2) Data analysis stage, in which the analysis is carried out until the discovery or expiration of the rules used in the analysis; and (3) Stage of presenting the results of data analysis, namely the presentation of findings that have been made after going through the analysis phase.

The first thing in providing data as mentioned in (1) is to look for words, phrases or sentences that have deviations both in terms of phonology, morphology, grammar, or semantics. The next thing is to show deviations that occur in words, which are then followed by directing the meaning literally and the actual meaning that the language games maker wants to show. Finally, as mentioned in point (3), which shows the result of data that have been analyzed regarding the language deviations. Then through this part, a red thread will be drawn related to language games made by the public against the government, namely how opinions are expressed in ways that makes it a joke on one side but also makes it harsh criticism on the other side.

The method used in finding the rules in this analysis is the padan (equivalent) method in which the determinant in the analysis is outside the language concerned. As for the decisive tool in this analysis is the fact that is appointed or language referents (Sudaryanto, 2015b, p. 15).

\section{FINDINGS}

There are two main findings that will be displayed in this section. The first finding is the forms of language games found on posters and banners carried by the demonstrators who were involved in voicing their opinions on the policy that will be launched. Thus, the language games that has been found are divided into several points namely, sound substitution and addition, abbreviation, polysemy, metaphor, idiom, entailment, and rhyme. 
The other finding that will be displayed in this section is language elements and functions. Language elements or also known as social factors in a language, are parts outside the language that determine the direction of the language creation. In this section, the language elements are based on the concept by Hymes (1989) namely SPEAKING. One other sub-finding that will be elaborated is the language function based on the concept by Jakobson (1960) that is divided into six language functions. According to Jakobson, even though language may contains a variety of functions, there will always be a function that dominates and that function is in one of six language functions such as emotive, conative or directive, referential, poetic, phatic, and metalingual functions.

\section{Forms of Language Games}

In September 2019 there had been a demonstration by college students who were members of various universities in several cities in Indonesia. In addition to calling for a rejection of the RUU KUHP 2019, the college students also displayed various writings in the form of posters and banners with various interesting words to be listened to. Furthermore, from the various writings, it is known that many of them contain various language games, as follows:

\section{Sound Substitution}

Several language games have been found in the form of phrases or sentences with words that have sound substitution, thus giving different meanings, such as the following data:

Table 1. Form of Language Game in Poster/Banner of the RUU KUHP 2019

\begin{tabular}{|c|c|c|}
\hline No & Form of Language Games & Data \\
\hline 1. & Sound(s) substitution & I'VE SEEN SMARTER CABINETS AT IKEA \\
\hline $\begin{array}{l}\text { near } \\
\text { kab } \\
\text { speal } \\
\text { has } t\end{array}$ & $\begin{array}{l}\text { Language games are fou } \\
\text { s "small cupboard" whi } \\
\text { nèt/ in Indonesian, mea } \\
\text { ers create language game } \\
\text { he same sound, the soun }\end{array}$ & $\begin{array}{l}\text { in the word "cabinet" / kabonit/ which } \\
\text { actually refers to the word "kabinet" } \\
\text { ng "institution or government council". } \\
\text { py substituting the letter "k" to "c" which } \\
\text { / } / \text { / at the beginning of the word, thus }\end{array}$ \\
\hline \multicolumn{3}{|c|}{$\begin{array}{l}\text { Sound Addition } \\
\text { Not much different from the previous data, speakers create language games } \\
\text { through the play of sounds in words like the following data: } \\
\text { Table 2. Form of Language Game in Poster/Banner of the RUU KUHP } 2019\end{array}$} \\
\hline No. & Form of Language Games & Data \\
\hline & Sound(s) addition & $\begin{array}{l}\text { WE ARE LIVING IN REPUBLIC NOT RAPE- } \\
\text { PUBLIC }\end{array}$ \\
\hline
\end{tabular}


The addition of sound as seen in the data, is located in the word "republic" / ri'pəblik/ which means 'a form of government sovereignty of the people' which experiences the addition of the letters "a" and "e" to the word "rape-public" / rāp-pəblik/ means 'rape in public'. The word "rape-public" by the speaker refers to public rights or the rights of the people whom the speaker thinks has been forcibly taken away.

\section{Abbreviation}

There are several abbreviations created by speakers by giving puns on the DPR abbreviation which is supposed to be an abbreviation of the "Dewan Perwakilan Rakyat" (House of Parliament). Some abbreviations used as writing include:

Table 3. Form of Language Game in Poster/Banner of the RUU KUHP 2019

\begin{tabular}{lll}
\hline No. & Form of Language Games & \multicolumn{1}{c}{ Data } \\
\hline 3. & & DEWAN PERSELANGKANGAN RAKYAT \\
& ngurusin selangkangan mulu! \\
4. & DEWAN PENINDAS RAKYAT (House of \\
5. & Oppressor) \\
& & DEWAN PALING RUWET (House of Most \\
& & Complicated) \\
\hline
\end{tabular}

The abbreviations follow the original shortened form, but with different content to create a satire on the body or institution of which the language is called. As shown in table 3, the word "Perwakilan" (Representative) is replaced by the word "Perselangkangan" (Crotch) while maintaining the initial letter " $\mathrm{P}$ " at the beginning of the word, so that it can still be abbreviated as "DPR". The same thing happens with other data where the word experiences change in the abbreviation of the letter " $\mathrm{P}$ " to "Penindas" (Oppressor). Then the letter " $\mathrm{P}$ " also experiences change of abbreviation from the word "Perwakilan" (Representative) to the word "Paling" (Most) and the letter " $\mathrm{R}$ " which changes from the word "Rakyat" (People) to "Ruwet" (Complicated)

\section{Polysemy}

Other data are language games in the form of using words with many meanings such as the following data:

Table 4. Form of Language Game in Poster/Banner of the RUU KUHP 2019

\begin{tabular}{lcl}
\hline No. & Form of Language Games & Data \\
\hline 6. & & KAMI YANG MINUM PEMERINTAH YANG \\
7. & Polysemy & MABUK \\
& & AKSI KAMI BUKAN KUDA \\
& & KAMI TIDAK DITUNGGANGI!!! \\
\hline
\end{tabular}

In the sentence above, a double meaning is created in the word "mabuk" (drunk) which first meaning is 'loss of consciousness due to drinks' and the second is meaning in the form of 'acting out of consciousness's. In 
general the use of the word "drunk" will refer to the first meaning, but the meaning of the speaker actually refers to the second meaning.

In the next data above, the word "ditunggangi" (ridden) also has double meaning consisting of 'ridden' and the second meaning consisting of 'increasing'. In line with the previous data, where the speaker is referring to the second meaning which is marked with the emphasis of the word "bukan $k u d a^{\prime \prime}$ (not horse), so the reader can understand the true meaning that the speaker wants to convey.

\section{Metaphor}

Language games can also be formed through the use of figurative words or words that contain metaphors like in the following data:

Table 5. Form of Language Game in Poster/Banner of the RUU KUHP 2019

\begin{tabular}{lllll}
\hline No. & Form of Language Games & \multicolumn{3}{c}{ Data } \\
\hline 8. & Metaphor & I DON'T NEED SEX & & \\
& & THE GOVERNMENT & IS & FUCKING ME \\
& & RIGHT NOW & & \\
& \#JanganMauDiperkosaNegara & \\
\hline
\end{tabular}

Speakers in the data above use the word abstract metaphor in the words "fucking" and "diperkosa" (raped). These two words are referred to by the speaker as deprivation of rights, not a form of physical rape.

\section{Idiom}

The next use of language style is the use of animal idioms as exposed in the following data:

Table 6. Form of Language Game in Poster/Banner of the RUU KUHP 2019

\begin{tabular}{lll}
\hline No. & Form of Language Games & Data \\
\hline 9. & Idiom & HEWAN TERNAK MASUK RUMAH \\
& & TETANGGA DIDENDA, \\
& & TIKUS BOBOL ANGGARAN NEGARA \\
& & DIBIARKAN \\
\hline
\end{tabular}

The animal livestock mentioned in the first phrase "hewan ternak" do refer to the animal livestock in literal, but the animal "tikus" (rat) in the second phrase refers to an idiom meaning "corruptor".

\section{Entailment}

The concept of entailment lies in the realm of discourse, which is a statement that follows what was stated in the previous speech. In this case, the language game is found in the form of an entailment as follows:

Table 7. Form of Language Game in Poster/Banner of the RUU KUHP 2019

\begin{tabular}{lll}
\hline No. & Form of Language Games & Data \\
\hline 10. & Entailment & ITU GEDUNG DPR ATAU HOTEL DEL \\
& & LUNA \\
& & KOK ISINYA SETAN SEMUA? \\
\hline
\end{tabular}


The phrase "Hotel del Luna" is a form of language game derived from the parody of a Korean drama of the same name. The phrase is associated with the word "setan" (devil), because the drama mentioned earlier is a drama with the actors and actresses playing the role of the spirit or "devil".

\section{Rhymes}

The language game found in the next data is the writing on the poster in the form of rhymes as seen in the following data:

Table 8. Form of Language Game in Poster/Banner of the RUU KUHP 2019

\begin{tabular}{lll}
\hline No. & Form of Language Games & \multicolumn{1}{c}{ Data } \\
\hline 11. & Rhyme & BIBIR DIKULUM \\
& & PANTAT DIGREPE \\
& & ASSALAMUALAIKUM \\
& TOLAK RUU KUHP \\
\hline
\end{tabular}

The speaker creates writing in the form of rhymes with the rhythm of $a-b-a-b$ based on the similarity of sounds at the end of words in each line. In the data, the content of rhymes is a form of exclamation to reject the RUU KUHP 2019.

\section{Language Elements and Functions}

Before entering into the explanation of the language functions contained in the writing of college students which contain language games, the language elements are first presented in the data. These elements are explained based on the SPEAKING analysis by Hymes (1974). The first element in the form of setting and scene is writing displayed by demonstrators in several cities in Indonesia such as several cities in Aceh, Padang, Palembang, Jakarta, Ciamis, Bandung, Serang, Banyumas, Jember, Yogyakarta, Kendari, Semarang, Surabaya, Malang, Makassar, Samarinda, Bali and several other cities. The majority of the demonstration sites are located around the House of Parliament (DPR) building which began in the afternoon. The time of the demonstration where the writing on the posters and banners are displayed starts on Thursday, September 26, 2019, continues on Friday, and resumed the following week on Monday, Tuesday and Thursday, until the last day of the following week on Monday, September 30, 2019.

As it is known, the participants who displayed the writings were students from several universities from each city who carried out the demonstration. The ends element is the students who have the aim of protesting and rejecting the RUU KUHP 2019, so that many of the writings found were used as satire, criticism, or to create humor.

Furthermore, the form of writing on posters and banners are phrases, sentences, rhymes and abbreviations where the act sequence contained in the writing is in the form of rejection and satire. The demonstration itself began calmly and casually so that the key element in the majority's writing 
was delivered in light language, but some of them were filled with abusive and sarcastic language.

Although in the demonstration, the instrumentalities used are in the form of oral and written, the analysis of this paper is only in the form of writing. On the other hand, the norms of language behavior in data tend to be one-way, that is, from students to the DPR and the government. There are also other interactions, namely interactions by the demonstrators themselves where students from various universities join into a mass gathering. Finally, the genre found in demonstrations is the writing in the form of posters and banners in the form of satire words, words of criticism, words of humor, and other words that are formed into language games.

Based on the forms of language games and language elements that have been delivered previously, the writings of the students that were found contain language functions that were divided based on what was emphasized in their speech. The language functions found in the data are as follows:

\section{Contextual Function}

Contextual functions are language functions that emphasize place or time (settings). Some of the data found seem to emphasize the context of place and time as seen in the following data:

Table 9. Language Function in Poster/Banner of the RUU KUHP 2019

\begin{tabular}{cll}
\hline No & Language Function & \multicolumn{1}{c}{ Data } \\
\hline 1 & & MAAF PERJALANAN ANDA TERGANGGU \\
& SEDANG ADA PERBAIKAN REFORMASI \\
& ALIANSI MASYARAKAT SIPIL UNTUK \\
& KEADILAN DAN DEMOKRASI \\
& CUTI NONTON DRAKOR \\
& KARNA DI DPR LEBIH BANYAK DRAMA \\
& & \\
3 & REZIM INI LEBIH KOTOR DARI KOSAN \\
& KAMI \\
\hline
\end{tabular}

Data no. 1 and no. 2 are forms of language game that has a contextual function that emphasizes the context of place. The emphasis on data no.1 which is a metaphorical language game is found in the second phrase which explains that there is a situation in that place which they called "perbaikan reformasi" (reformation restoration). Emphasis in detail is given on data no. 2 which is a form of polysemic language game, in which the speaker emphasizes the phrase "di DPR" (in the DPR).

Another data has a contextual function that provides emphasis on time as seen in data no. 3:

The word "rezim" (regime) means 'ruling government'. Speakers emphasize by creating the phrase "rezim ini"(this regime) which means the 
time of government in power when the writing was made that refers to the governance period 2014-2019.

\section{Emotive Function}

The emphasis on this function is the speaker himself so that the language function can be seen through the feelings conveyed through the speakers' writing such as the following data:

Table 10. Language Function in Poster/Banner of the RUU KUHP 2019

\begin{tabular}{lll}
\hline No & \multicolumn{1}{c}{ Language function } & \multicolumn{1}{c}{ Data } \\
\hline 4. & Emotive function & Cukup Perasaanku Ke Kamu Yang Mati, \\
& & Demokrasi Jangan \\
& \#SahkanRUUPKS \\
& \#TundaRKUHP \\
& \#MosiTidakPercaya \\
\hline
\end{tabular}

In data above the speaker creates a metaphorical language game through the word "mati" (dead), but at the same time the speaker conveys an emotion of disappointment by comparing what he feels with her lover with the conditions of democracy.

\section{Conative or Directive Function}

In addition to the two functions mentioned earlier, the writing on posters and banners also contains conative or directive functions that are manifested in the form of an appeal or order. One of the data appears to contain this function, namely:

Table 11. Language Function in Poster/Banner of the RUU KUHP 2019

\begin{tabular}{ccc}
\hline No & Language function & Data \\
\hline 5 & Directive function & PAK POLISI JANGAN TEMBAK SAYA!! \\
& & KARNA $\bullet$ INI HANYA UTK DIA \\
\hline
\end{tabular}

The data above is a form of polysemic language game with a double meaning on the word "tembak" (shoot). The conative or directive function is manifested in the form of sentences or commands as evidenced by the word "jangan" (don't) in the data.

\section{Referential Function}

This function prioritizes the content or topic of conversation to convey the message desired by the speaker. One form of writing that contains a referential function is seen in data no. 7 in table 4 where the speaker expresses his rejection of the alleged demonstration of being "ridden" (ditunggangi).

\section{Poetic Function}

In this function, the speaker emphasizes the form of the message or writing to be conveyed. One of the data shows that the speaker creates a message or writing in the form of rhythm as seen in data no. 11 in table 8. 
The Phenomena Language Games as College Students Responses...

\section{Phatic Function}

The phatic function is the function of language when the center of attention is the connection of speech, so that the line of speech such as at the beginning or end of a conversation is not interrupted. The phatic function can be seen in the following data:

Table 12. Language Function in Poster/Banner of the RUU KUHP 2019

\begin{tabular}{lll}
\hline No. & Language function & Data \\
\hline 6. & Phatic function & INI INDONESIA APA ISEKAI? \\
& & KOK SAYA WIBU IKUT DEMO \\
\hline
\end{tabular}

Speakers in the data above make a question in the first sentence which is then followed by a statement in the second sentence, so that the speech is connected without interruption. This function often arises in writing containing language games aspects of the discourse of entailment, because the phrases or sentences included in the entailment will follow what is emphasized in the previous phrase or sentence.

\section{Metalinguistic Function}

The last language function found in the data is a metalinguistic function that is manifested in a language that focuses on certain meanings or terms as contained in definitions or formulas. In the following data, it is seen that the speaker creates insinuating writing using terms that are limited to certain diseases, namely:

Table 13. Language Function in Poster/Banner of the RUU KUHP 2019

\begin{tabular}{lll}
\hline No. & Language function & Data \\
\hline 7. & Metalinguistic function & DIBUTUHKAN DOKTER THT \\
& & DPR KAMI TULI!!! \\
& & TIDAK BISA MENDENGAR RAKYAT
\end{tabular}

The abbreviation for "THT" (ENT) is "telinga, hidung dan tenggorokan" (ear, nose and throat), so the phrase "dokter THT" (ENT doctor) is defined as a doctor whose specialty is a disease related to the ear, nose and throat. The term THT has so far been limited to this disease, but speakers have created language games that contain insinuations that when the "DPR" mentioned in writing does not listen to the people, the ear of them must be healed so that they can hear the opinions or aspirations of the people.

\section{DISCUSSION}

Based on the results of the analysis, it is known that language games are found in every region that conducts demonstrations in Indonesia. There was no agreement among the students in making posters and banners, but unexpectedly they created similar language games. This indicates that the students' thoughts in creating language games are in the same mindset. Possibilities that cause similarities in creating language games are age factor which is in the adjacent age range, the same social status which is college 
student, and the context of a demonstration that is the rejection of the RUU KUHP 2019. This is in line with what is said by Nasution \& Ayuningtyas (2020) that language choice used by the speaker is indeed influenced by the situation of the speaker's social community. It was also stated that age and level of education can influence language choice when communicating with others. Another reason that might be the cause of the similarity of language games is social media because students who have not yet held a demonstration can mimic the style of language games that have been carried out by students who have uploaded them to their social media.

Furthermore, if we glance from the previous research, then this research has a little more in common with the research related to language style. This is because language games basically originate from the use of language styles by its users. In one study by Rullyanti \& Nurdianto (2019) of a stand-up comedian for example, which stated that they believed that language styles such as figurative language were used by speakers with the aim of attracting the audience while giving deep feeling to his comedy. This further emphasizes that to attract attention requires the addition of language games or figurative language, because even if the language is not delivered to the target, at least the language created has produced a sensation and discussion around it.

\section{CONCLUSION AND SUGGESTION}

Based on the analysis, it can be concluded several points namely, students who take part in demonstrations deliberately make language games with various forms; language games are made as a form of harsh critic but are wrapped in humor in order to attract the attention of the intended target and the readers who read it; and language is not just formed, but is influenced socially, so it can be said that language product is created due to various aspects both intentionally or not. Then, as mentioned before about the form of language games, it is known that there are several forms of language games found such as, sound substitution, sound addition, abbreviations, metaphor, polysemy, idiom, entailment, and rhymes and can occur in words, phrases, or sentences. The language game contains several language functions such as, contextual functions, which emphasizes place and time, emotive that describe the feelings of the speaker, directives that contain instructions or requests, referential that prioritize the contents of the conversation, poetic that prioritizes the form of speech, phatic that prioritizes the connection of speech and meta-linguistics that uses certain terms. Simply stated, these writings were created with various objectives such as satire and criticize related policies, make fun of the performance of related parties, and just to create humor. 
The Phenomena f Language Games as College Students Responses...

Eventually, it was discovered that the range of languages used by speakers was a mixture of formal and casual languages. Formal languages are characterized by complete forms of words and sentences, while casual languages are characterized by non-standard language use. The mixture of the two languages is due to the act of the speaker who creates writing using complete and inaccurate words and sentences. The inaccuracy is a form of intent to create deviations of linguistic aspects of language games. The existence of two languages reflects the distance between the speaker and the speech partner but is in an unofficial situation so there are no rules that bind the speaker to create an accurate language.

\section{REFERENCES}

Fatonah, N. (2017). Permainan Bahasa dalam Wacana Humor pada Akun Meme Comic Indonesia di Instagram serta Implikasinya pada Pembelajaran Bahasa Indonesia di SMA [Universitas Lampung]. http:/ / digilib.unila.ac.id/id/eprint/29003

Foucault, M. (2018). The Order of Things. Routledge. https://doi.org/10.4324/9781315660301

Fuady, M. (2005). Filsafat dan Teori Hukum Postmodern (1st ed.). Citra Aditya Bakti.

Hartini, L. (2019). Tata Permainan Bahasa “Wittgenstein" dalam Teks Konstitusi. Jurnal Wawasan Yuridika, 3(No.1), 41-54. https://doi.org/http://dx.doi.org/10.25072/jwy.v3i1.204

Hymes, D. (1974). Foundations in Sociolinguistics: An Ethnography Approach. Philadelphia: University of Pennsylvania Press.

Hymes, D. (1989). Ways of Speaking. In Explorations in the ethnography of speaking, 1, 433-451.

Jakobson, R. (1960). Linguistics and Poetics. Style in Language, Cambridge, MA: M.I.T. Press, 350-377

Kinantia, K. P \& Nurdahliah, D. U. (2018). Pengaruh Penggunaan Teks Permainan Bahasa terhadap Prestasi Mahasiswa pada Mata Kuliah Morfologi. Kembara, 4(1), 56-62. http:/ / ejournal.umm.ac.id/index.php/ kembara/article/view/5269

Nasution, V. A., \& Ayuningtyas, N. (2020). THE LANGUAGE CHOICE OF CHINESE COMMUNITY IN MEDAN: A SOCIOLINGUISTICS STUDY. JOALL (Journal of Applied Linguistics \& Literature), 5(1), 11-25. https://doi.org/10.33369/joall.v5i1.9063

Rullyanti, M., \& Nurdianto, N. (2019). LANGUAGE STYLE OF HUMOR ON STAND-UP COMEDY VIDEO. JOALL (Journal of Applied Linguistics $\mathcal{E}$ Literature), 4(1), 60-68. https:/ / doi.org/10.33369/joall.v4i1.6886

Saputri, D. (2015). Permainan Bahasa pada Plat Nomor Kendaraan Bermotor (Suatu Kajian Sosiolinguistik). Jurnal Majalah Kreasi STKIP MPL, 15(1). 
Sudaryanto, D. P. (2015). Metode dan Aneka Teknik Analisis Bahasa: Pengantar Penelitian Wahana Kebudayaan Secara Linguistis. Sanata Dharma University Press.

Turnbull, N. (2005). Bengkel Ilmu: Filsafat. Erlangga.

Wibowo, W. (2006). Berani Menulis Artikel: Babakan Baru Kiat Menulis Artikel untuk Media Massa Cetak. Gramedia Pustaka Utama.

Wijana, I. D. P. (2003). Kartun: Studi Tentang Permainan Bahasa. Ombak.

Wittgenstein, L., \& Brown, D. A. (2017). The Routledge Handbook of Philosophy of Memory (S. Bernecker \& K. Michaelian (eds.)). Routledge.

https://doi.org/10.4324/9781315687315

Yuwono, U. \& Lauder, M. R. M. T. (2007). Pesona Bahasa: Langkah Awal Memahami Linguistik. Gramedia Pustaka Utama. 